\title{
VÝSKUM BOJÍSK DRUHEJ SVETOVEJ VOJNY NA JUHOZÁPADNOM SLOVENSKU
}

\author{
Východiská a perspektívy
}

\author{
PAVOL ك̌T E I N ER
}

\begin{abstract}
Research of the Second World War Battlefields in Southwestern Slovakia. Resources and Perspectives. Area of southwestern Slovakia was a stage of heavy fighting in the last months of the second world war. Currently, the most accute aim of interdisciplinary research, both historical and archaeological, is to specify the exact position of battlefields, artillery and defense positions. It is also the matter of protection of these sites to save them from the illegal archaeological activities.
\end{abstract}

Keywords: Southwestern Slovakia, Second World War, second world war, battlefield, archaeological research, archaeology of conflicts, archaeology of modernity.

\section{ÚVOD DO PROBLEMATIKY}

Hlavnú úlohu archeológie predstavuje od jej počiatkov dokumentovanie dejín ludstva na základe hmotných prameňov. Chronologická hranica skúmania sa v priebehu vývoja tohto vedného odboru posúvala. Od počiatočnej fascinácie antikou či pravekom cez výskum stredoveku až po novšie obdobia. Najneskôr od 60 . rokov 20. storočia sa archeológia zameriava aj na výskum relatívne mladých období vrátane prvej a druhej svetovej vojny.

Situácia v slovenskej archeológii je obdobná, avšak s dodatkom, že vývoj archeológie modernity, ako sa zvykne toto odvetvie označovat' (Vařeka 2013, 7-11), má oproti väčšine susedných regiónov meškanie jednu až dve dekády.

Analýza príčin, prečo sa u nás doposial' nevenovala archeológii moderných konfliktov adekvátna pozornost', by si snád' zasluhovala špeciálnu štúdiu. Skúsme načrtnút aspoň hrubé obrysy. Jedným z dôvodov môže byt' skutočnost', že ani historiografický výskum daného obdobia nie je na Slovensku dostatočne rozvinutý. Pre archeologické bádanie tak chýbalo spracovanie základných písomných prameňov. To už však neplatí, ked’že za ostatných 10-15 rokov vyšlo viacero publikácií, ktoré dost' podrobne mapujú napr. tzv. malú vojnu, boje SNP či frontové operácie na prelome rokov 1944 a 1945 (napr. Klubert 2007; 2014; Mičianik 2019; Šteiner 2018; 2019a). Ostatné príčiny zaostávania však treba hladat' vo vnútri slovenskej archeologickej komunity: absencia špecialistov, donedávna absencia výuky tohto segmentu na vysokých školách, nezáujem aktívnych archeológov... Napriek tomu, že sa militárie z druhej svetovej vojny dostávali ako nálezy z terénnych výskumov do zorného pola archeológov, nevenovala sa im takmer žiadna pozornost', o ich systematickej evidencii a spracovaní nehovoriac.

Pritom aktuálna legislatíva explicitne spomína militárie vyrobené do roku 1946 ako archeologické nálezy, $\mathrm{v}$ prípade, že sa nájdu pod zemským povrchom alebo pod vodou (Zákon č. 49/2002, §2, ods. 5). Kladie ich teda na úroveň akýchkolvek iných artefaktov, s ktorými archeológia pracuje.

Vzhladom na tieto skutočnosti, ako aj na fakt, že militárie z druhej svetovej vojny sú častým predmetom nelegálnej činnosti, je najvyšší čas venovat' sa tejto problematike systematicky aj na Slovensku.

\section{HISTORICKÝ KONTEXT}

Hoci druhá svetová vojna postihla vo viacerých časových horizontoch celé územie Slovenska bez výnimky, dajú sa vyčlenit’ regióny, v ktorých sa bojové operácie odohrali $v$ omnoho väčšom meradle než inde. V hrubých kontúrach takto môžeme menovat niekol'ko oblastí, kde sa dá z vyššie uvedeného dôvodu počítat's väčšími kumuláciami militárií:

- širšia oblast’ okolo Duklianskeho priesmyku (september 1944 - január 1945)

- stredné Slovensko, najmä priestor Nízkych Tatier, Vel'kej Fatry a Slovenského rudohoria (SNP, september, október 1944)

\footnotetext{
1 Príspevok je jedným z výstupov projektu APVV-17-0199: Kultúrny produkt regionálneho múzea v kontexte objektívnej spoločenskej potreby: Život v totalite v rokoch 1939-1945.
} 
- juhozápadné Slovensko: dolné toky Ipla, Hrona, Žitavy, Nitry a Váhu, eventuálne až po Moravu (december 1944 - apríl 1945)

Spomedzi uvedených oblastí sa svojím historickým významom vymyká tretia menovaná. Bola totiž dejiskom najrozsiahlejších bojov, kedže sa stala súčastou strategického budapeštiansko-viedenského smeru Červenej armády. Ide najmä o územie terajších okresov Levice, Nové Zámky a Komárno, eventuálne susediacich okresov (Šala, Krupina, Nitra, Zlaté Moravce). V porovnaní s inými bojiskami sa tu koncentrovalo zd’aleka najväčšie množstvo pechoty, obrnených vozidiel, letectva a na Dunaji dokonca aj bojové plavidlá. Nepretržitá bojová činnost̉ počas piatich mesiacov, pričom napríklad na dolnom Hrone front stál celé tri mesiace, nemohla nezanechat rozsiahle stopy. Tie koniec-koncov vidíme čiastočne dodnes napríklad v podobe chýbajúcej historickej zástavby v niektorých mestách a obciach, či mostov, ktoré museli byt' po vojne obnovené. V regióne sa aj po 75 rokoch stále objavujú početné náhodné nálezy munície.

Frontové operácie sa do sledovaného regiónu preniesli v polovici decembra 1944 dobytím Šiah Červenou armádou. Následne sa tažisko bojov presunulo do medziriečia Ipla a Hrona, kde sa odohrala séria často až chaotických tankových zrážok. Tieto strety vyústili v posledných dňoch roka do evakuácie vojsk Osi za Hron severne od Štúrova.

6. januára 1945 zbory sovietskeho 2. ukrajinského frontu zaútočili smerom na Komárno a Nové Zámky. Spočiatku úspešne sa rozvíjajúcu ofenzívu zastavilo nepriaznivé počasie a nasadenie nemeckých obrnených záloh. Výsledkom januárových bojov sa stalo vytvorenie tzv. hronského predmostia Červenej armády.

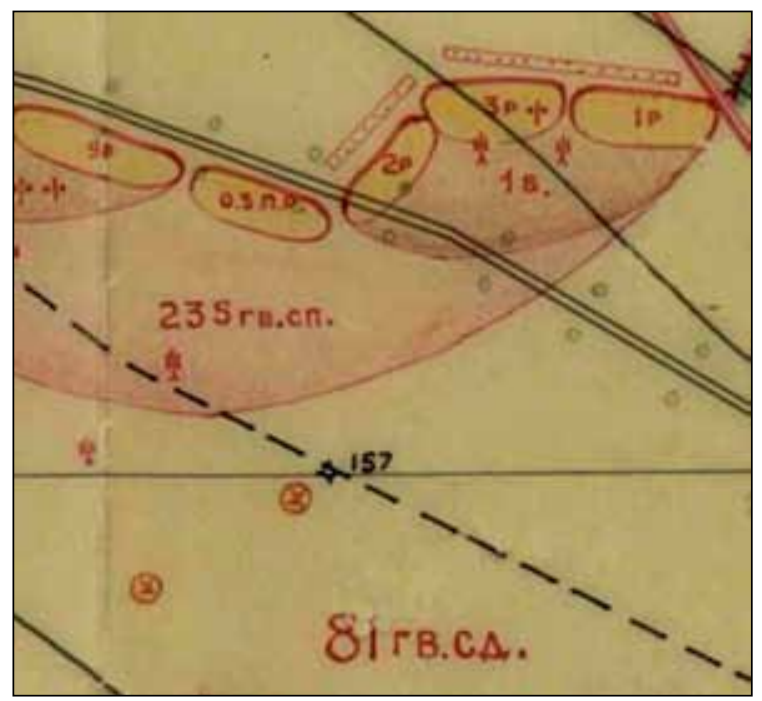

Obr. 1. Príklad mimoriadne podrobnej situačnej mapy (zdroj: https://pamyat-naroda.ru).
Na elimináciu tohto predmostia prisunulo nemecké velenie dva tankové zbory, ktoré ho počas operácie s krycím názvom Südwind v druhej polovici februára 1945 počas ôsmich dní neobyčajne tažkých bojov zlikvidovali.

Poslednú fázu vojnových operácií na juhozápadnom Slovensku predstavuje bratislavsko-brnianska operácia Červenej armády, ktorá sa začala 25. marca 1945 prekročením Hrona. Počas nej sa frontová línia rýchlo posúvala na západ: v prvých dňoch apríla sa Sovieti dostali cez Váh a o týždeň už prekračovali Moravu do Dolného Rakúska. Boje sa na danom území definitívne skončili.

\section{PÍSOMNÉ PRAMENE A ICH VYUŽITIE}

Na podrobnú rekonštrukciu priebehu bojov sa v súčasnosti dá využit široká škála písomných a mapových prameňov. Treba však poznamenat', že v slovenských archívoch sa nachádza len vel'mi málo relevantných prameňov, a preto ich treba hl'adat' $\mathrm{v}$ zahraničí. Vel'kú pomoc našim bádatelom poskytujú hlavne ruské archívy $\mathrm{v}$ gescii tamojšieho ministerstva obrany, ktoré vol’ne v digitalizovanej podobe sprístupňujú svoje obrovské fondy. Ide najmä o server pamyat-naroda.ru, kde sú zverejnené dokumenty jednotiek Červenej armády. Rovnako užitočné sú tiež Sovietmi ukoristené písomnosti nemeckých štábov, publikované prostredníctvom serveru wwii.germandocsinrussia.org.

Takto máme $\mathrm{k}$ dispozícii primárne písomné pramene oboch hlavných bojujúcich armád, vd’aka ktorým dokážeme pomerne presne lokalizovat' miesta bojov či priebeh obranných línií. Okrem týchto zdrojov nesmieme zabúdat na pramene týkajúce sa mad’arskej, rumunskej či slovenskej armády či memoárovú literatúru (Šteiner 2019b).

Práca $s$ týmito prameňmi pochopitelne nie je jednoduchá. Okrem jazykových znalostí vyžaduje skúsenosti s dobovou vojenskou terminológiou, žargónom, identifikovanie skratiek a mnoho iných dôležitých detailov. Výsledkom v optimálnom prípade môže byt' mimoriadne presné lokalizovanie miest bojov či bojových pozícií.

Kvalita jednotlivých prameňov býva rôzna. Najkomplexnejšie a najpodrobnejšie informácie prirodzene poskytujú hlásenia jednotiek. Vo všeobecnosti platí, že čím nižší stupeň velenia (divízia, pluk, prápor), tým hodnotnejšie a detailnejšie údaje pre možný archeologický výskum bojiska môžeme očakávat. $\mathrm{V}$ prípade vyšších celkov (skupiny armád, fronty, armády, zbory) máme $\mathrm{k}$ dispozícii menej podrobné informácie, avšak sú dôležité pre kontrolu a overenie faktov. 


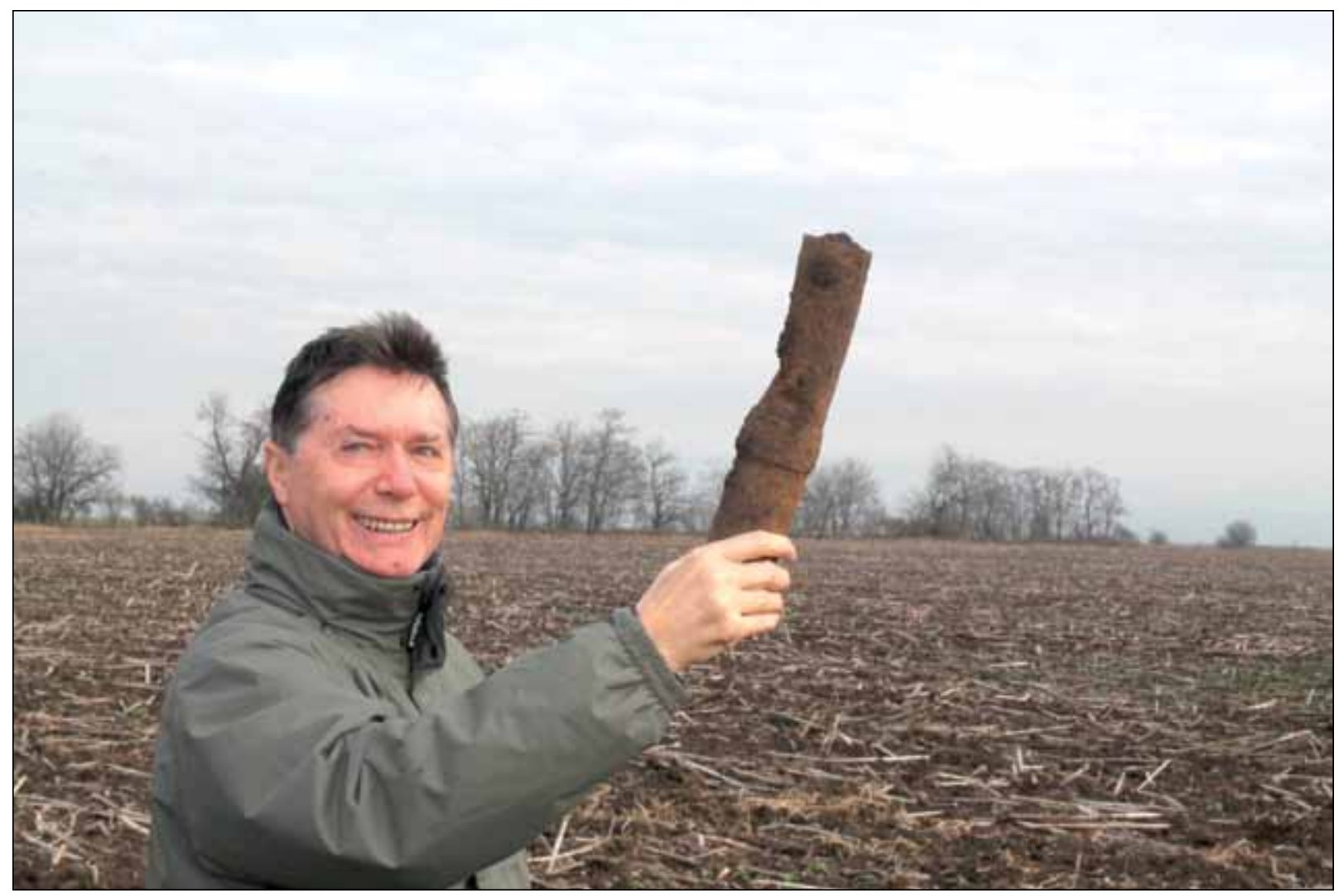

Obr. 2. Prof. J. Bátora s nábojnicou sovietskeho delostreleckého protipancierového granátu kalibru 76,2 mm, nájdenou pri prieskume zaniknutej samoty Bibit puszta (archív autora).

V ideálnom prípade (ale ani zd’aleka nie často) sú hlásenia doplnené o situačné mapy. Vdaka nim môžeme konkretizovat nielen priebeh línie, ale aj iné objekty či typ umiestnenej výzbroje (obr. 1). ${ }^{2}$

Pri identifikácií jednotlivých bojísk a postavení je tiež nutné porovnávat písomné pramene s dostupnými mapami oblastí. Ide predovšetkým o dobové mapy, ktoré zachytávajú terén $\mathrm{v}$ podobe, $\mathrm{v}$ akej sa nachádzal v 40. rokoch 20. storočia. Doposial' sa najviac osvedčili špeciálne mapy vojenského mapovania ČSR z r. 1938 1:75 000, železničná mapa CSR 1:75 000 a mad'arské vojenské mapovanie z r. 1941.

Na týchto mapách nielenže vidíme aktuálny stav terénu, ale nachádzajú sa tu aj pôvodné toponymá a aj čísla topografických kót sa väčšinou zhodujú $\mathrm{s}$ údajmi $\mathrm{v}$ hláseniach a situačných mapách. Tieto údaje sú tiež dôležité pri presnej identifikácií bojísk. Vyhladat historický názov konkrétnej obce v encyklopedických publikáciách väčšinou nie je problém. Ten nastáva $\mathrm{v}$ prípade chotárnych častí, samôt či majerov, z ktorých mnohé už nestoja, spojili sa s obcami, alebo sa na novších mapách vyskytujú pod iným názvom.

Kombináciou uvedených metód sa v novembri 2018 podarilo spoločnými silami Katedry muzeológie FF UKF v Nitre a Katedry archeológie FF UK v Bratislave identifikovat polohu zaniknutej samoty Bibit puszta v katastri obce Bruty, ktorá sa vo februári 1945 stala miestom tažkých tankových zrážok (Šteiner 2013). Táto samota bola počas bojov úplne zničená a po vojne ju už neobnovili. Na jej mieste sa nachádza polnohospodársky využívaná pôda - pole. Kedže lokalita nebola dlho osídlená (vznikla pravdepodobne až po prvej svetovej vojne), vyskytla sa iba na dvoch dobových mapách a na situačných mapách sovietskej 72. a 81. gardovej streleckej divízie. Povrchový prieskum zistil s využitím písomných hlásení jednotiek, memoárov účastníkov bojov a situačných máp jednak prítomnost väčšieho množstva kovových militárií a jednak vd’aka koncentrácii fragmentov tehlového muriva aj polohu, kde stáli tri objekty zaniknutej samoty (obr. 2).

\footnotetext{
2 Z dôvodu, že väčšina lokalít ešte nebola preskúmaná, zobrazujeme príklady objektov bez uvedenia presnej polohy. V prípade záujmu odborníkov poskytne informácie autor príspevku.
} 


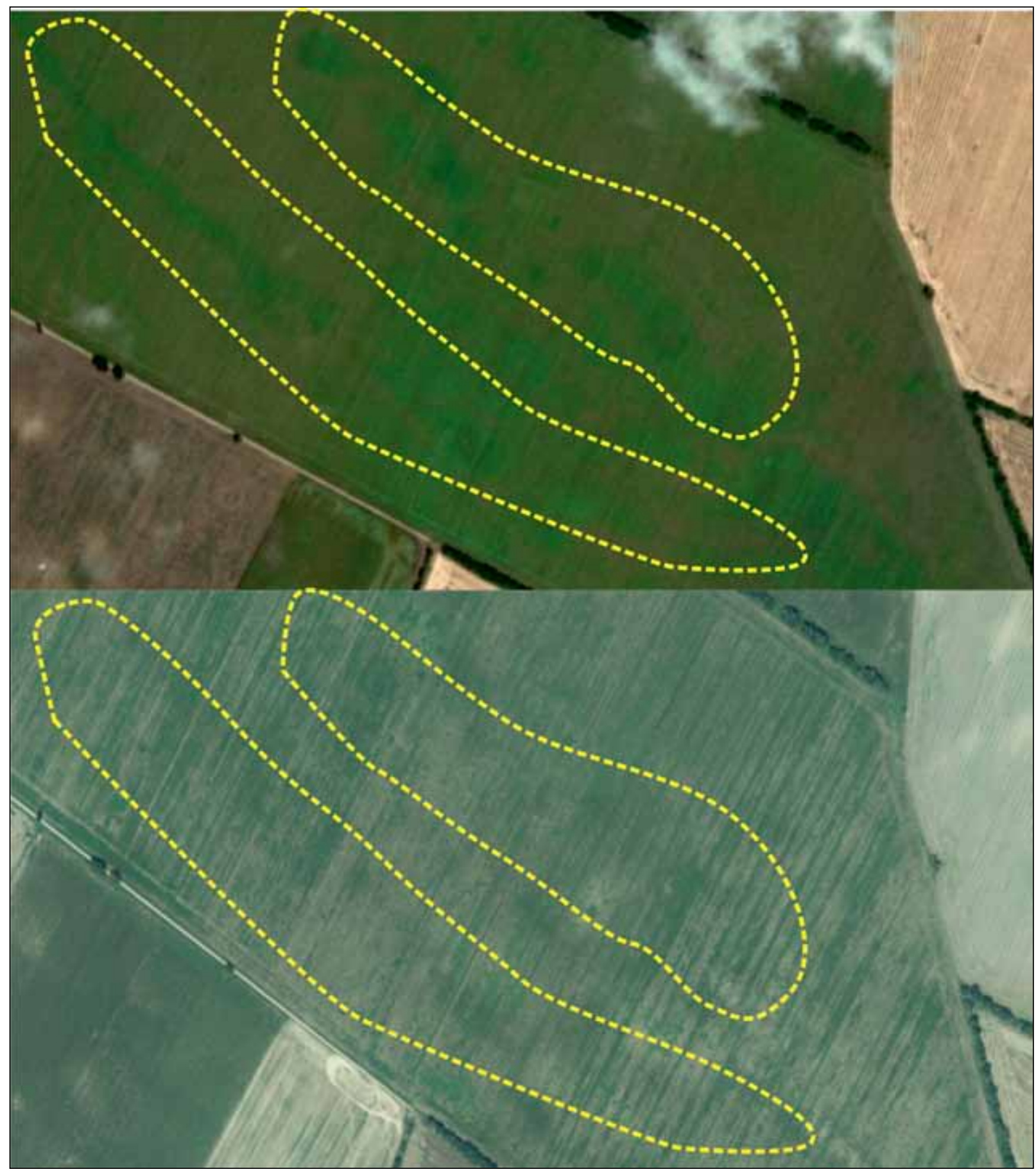

Obr. 3. Porovnanie satelitných záberov lokality zaniknutej samoty Bibit puszta pri rôznych podmienkach (zdroj: https:// zbgis.skgeodesy.sk).

\section{PROSPEKCIA OBJEKTOV}

Inú kvalitu výskumu predstavuje vyhladávanie vojenských polných objektov. Tieto zanechávajú viac alebo menej výrazné stopy $\mathrm{v}$ teréne. $\mathrm{V}$ prípade objektov $\mathrm{z}$ druhej svetovej vojny musíme mat na zreteli, že od ich vzniku uplynulo necelých osem dekád, a preto sa zväčša javia inak než pra- veké, stredoveké alebo včasnonovoveké objekty. Výrazne limitujúcim faktorom je v tomto prípade intenzívna polnohospodárska činnost', čo sa týka predovšetkým bojísk na juhozápadnom Slovensku. Orba a iné spôsoby obrábania pôdy spôsobili, že pri sledovaní štandardných leteckých a satelitných snímok terénu sa polné vojenské objekty z druhej svetovej vojny dajú len vel'mi tažko identifikovat', 


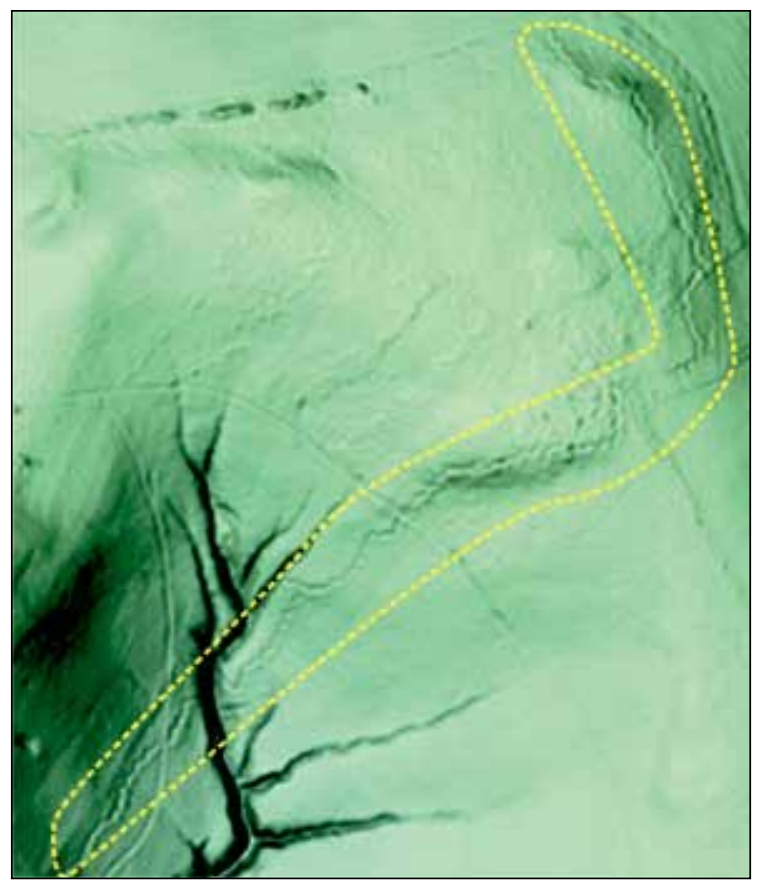

Obr. 4. Súvislý pás polných opevnení Wehrmachtu na snímkach LIDAR (zdroj: https://zbgis.skgeodesy.sk).

respektíve odlíšit od iných objektov a prírodných útvarov (napr. zaniknuté korytá vodných tokov). Doterajšie skúsenosti poukazujú na skutočnost', že ideálne pozorovania spočívajú v porovnávaní snímok jednej a tej istej lokality, urobených za rôznych podmienok či v rôznych ročných obdobiach (obr. 3).

Výrazný negatívny vplyv na optickú identifikáciu objektov mala aj rozsiahla meliorácia vodných tokov, ktorá prebehla v 50. a 60. rokoch. Tá ich často umelo vyrovnávala a likvidovala prirodzenú konfiguráciu terénu. Vzhladom na to, že na juhozápadnom Slovensku sa boje v rokoch 1944 a 1945 odohrávali najmä v povodí dolných tokov riek (Ipel', Hron, Nitra, Váh), musíme predpokladat', že väčšina polných opevnení z týchto mesiacov bola vodohospodárskou činnostou úplne zničená.

Obrovskú pomoc pri zistovaní prítomnosti polných objektov však prináša laserové mapovanie terénu, LIDAR (Light Detection And Ranging). Hoci sme aj túto metódu na Slovensku začali aplikovat' neskôr ako napríklad v ČR, od prvého nahliadnutia do sprístupnených oblastí je zrejmé, že sa stane nesporným prínosom pre archeológiu moderných konfliktov. Ǔčinnost' LIDAR-u spočíva hlavne v tom, že zobrazuje terén bez rastlinného pokryvu a pri vhodnom nastavení dokáže zachytit’ aj nerovnosti nezistitel'né inými metódami pozorovania.

Vyššie zmienená vysoká polnohospodárska aktivita na bývalých bojiskách spôsobila takmer úplné zahladenie vojenských objektov. Jediné, ktoré sa

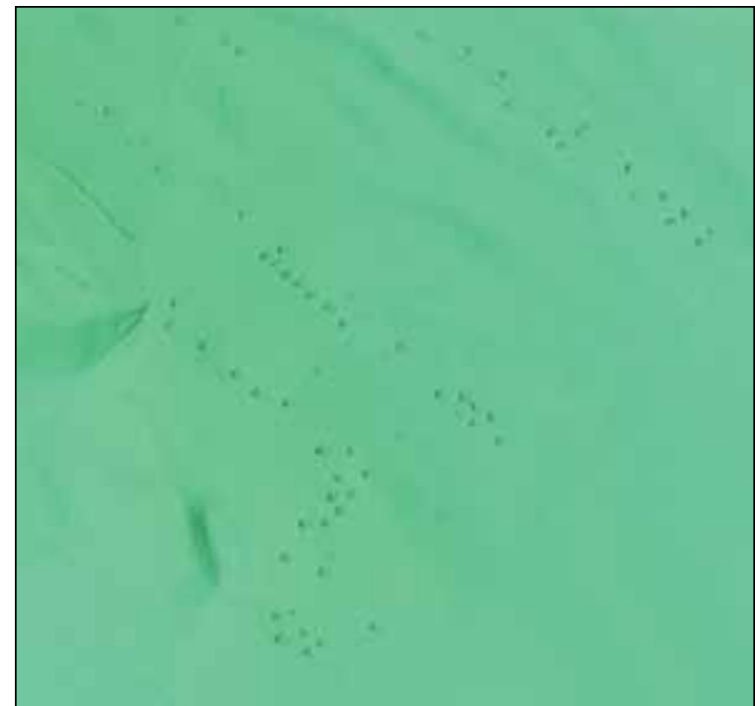

Obr. 5. Zemnice na ubytovanie vojakov pravdepodobne Červenej armády na snímkach LIDAR (zdroj: https://zbgis. skgeodesy.sk).

tomu vyhli, sú objekty vyskytujúce sa v pôvodných lesných porastoch. Tých je síce na juhozápadnom Slovensku v porovnaní s inými regiónmi podstatne menej, ale dost' na to, aby sme v nich vdaka LIDAR-u dokázali zachytit hl’adané objekty. Naštastie obranné zariadenia ako zákopy a okopy budovali bojujúce strany vel'mi často na úpätiach alebo hrebeňoch výšin, ktoré boli a dodnes sú zalesnené. Vd’aka tejto skutočnosti a aj vd’aka tomu, že porasty (háje, remízy) neboli neskôr mechanicky upravované (nie všetky), sa tu objekty zachovali a vidno ich na snímkach laserového mapovania.

Takto sa podarilo doposial' identifikovat niekol'ko desiatok objektov: jednoduchých zákopov, celých zákopových systémov, jednoduchých okopov a ich zhlukov. Spravidla sa ich účel dá určit podla tvaru a usporiadania. Najlahšie sa stotožňujú zákopy charakteristického cikcakového pôdorysu. Tie sa najčastejšie vyskytujú $\mathrm{v}$ dížke rádovo desiatok metrov, čo predstavuje zhruba bojový priestor pre pešie družstvo až čatu. V precízne vybudovaných a dobre zachovaných zákopoch identifikujeme aj strelecké predprsne či predsunuté postavenia pre gulomety alebo mínomety.

Výnimočne sa darí zistił tiež celé zákopové systémy v dížke rádovo stoviek metrov až niekol'kých kilometrov(!). Spravidla majú zložitejšiu štruktúru s výbežkami do viacerých smerov, niekedy dokonca viaclíniovú (obr. 4).

V blízkosti zákopov a zákopových systémov sa často objavujú, taktiež v lesnom poraste, početné zahíbené objekty, niekedy nápadne zoradené do radov, oválne alebo mierne pravouhlé s dížkou 
najčastejšie niekol'ko metrov, pričom najväčšie dosahujú bezmála $20 \mathrm{~m}$ (obr. 5). Predbežne sa možno domnievat', že ide o zvyšky zemníc, slúžiacich na ubytovanie mužstva. Objekty tohto druhu, umiestnené na hrebeňoch a temenách výšin naznačujú, že slúžili ako palebné postavenia pre delostrelectvo alebo pozorovatelne. U najväčších sa dokonca dá uvažovat', že sú to zvyšky okopov pre tanky.

Takáto, hoci predbežná interpretácia, je možná aj vd’aka doterajším znalostiam písomných prameňov. Z nich vieme, že v oblastiach obzvlášt hustej koncentrácie zahíbených objektov sa naozaj v určitých obdobiach zhromažd’ovali vel'ké počty vojakov, napríklad pri zhromaždovaní jednotiek nemeckého 1. tankového zboru SS pre operáciou Südwind severne od Svodína, či po ústupe sovietskeho 25. gardového streleckého zboru počas zmienenej operácie, kedy sa rozbité divízie zboru sústredili medzi Hronom a Iplom východne od Kamenína.

Rovnako aj zákopy a ich systémy sa dajú dobre stotožnit’s konkrétnymi operáciami a konkrétnymi dátumami. Stačí vyhodnotit polohu a orientáciu zákopov a porovnat ich so známymi vojenskohistorickými faktami a dokážeme stanovit ajjednotky, ktoré ich uživali.

\section{VÝZNAM VÝSKUMU BOJÍSK DRUHEJ SVETOVEJ VOJNY}

Vzhladom na to, že militárie druhej svetovej vojny sú zo zákona rovnocennými archeologickými artefaktami, musí im byt’ venovaná aj rovnocenná pozornosṫ z hladiska archeologického, muzeologického a monumentologického. Mapujú dôležité obdobie našich dejín a ich interdisciplinárnym výskumom rozširujeme poznanie obdobia, o ktorom sme ešte donedávna mali iba hmlisté predstavy.
Význam výskumu bojísk vzrastá aj kvôli tomu, že sa nezriedka stávajú objektom záujmu nelegálnych hladačov militárií. Škodu spôsobujú jednak tým, že neodborne vyzdvihujú artefakty bez náležitej dokumentácie a ošetrenia a jednak tým, že s nimi obchodujú, žial' často aj do zahraničia. Už len samotný prieskum a identifikácia bojísk ich zaevidovaním v databáze CEANS povýši na archeologické lokality, a tak sa dostanú pod ochranu zákona. Táto skutočnost’ síce sama o sebe militárie neochráni, ale s patričným prehladom o jednotlivých lokalitách budeme mat aspoň možnost̉ ich dôsledne pozorovat a v spolupráci s PZ SR snád’ aj účinne zasahovat’ proti nelegálnym výkopom.

Okrem riešenia dôsledkov by sa naša činnost' mala zamerat' aj na systematický výskum predmetnej oblasti. Doposial' sa žiadne vedecké ani múzejné pracovisko nevenuje zámernému skúmaniu bojísk druhej svetovej vojny. Ide iba o individuálne aktivity jednotlivcov, pre ktorých je to len jedna $\mathrm{z}$ mnohých činností, ktoré musia $\mathrm{v}$ rámci svojho pracovného zaradenia vykonávat'.

Za ideálnych podmienok by však mohlo vzniknút špecializované pracovisko, ktoré by spájalo obe zložky výskumu: historickú (zhromaždovanie, štúdium, interpretácia písomných a mapových prameňov) a archeologickú (prospekcia, terénny výskum). Eventuálne by sa $\mathrm{k}$ nim mohla pridružit’ aj muzeologicko-monumentologická zložka, zameriavajúca sa na prezentáciu hnutelných aj nehnutel’ných nálezov.

V súčasnosti, ked' sa systematický výskum bojísk druhej svetovej vojny len rozbieha, treba predovšetkým čím skôr vykonat' najnutnejšie kroky na výskum, ale aj ochranu zistených objektov, aby tak boli základom pre d’alší rozvoj tejto vetvy archeológie na Slovensku.

\section{LITERATÚRA}

Klubert 2007 - T. Klubert: Obrnené jednotky v Slovenskom národnom povstaní. Nové Mesto nad Váhom 2007.

Klubert 2014 - T. Klubert: Smrt' sa volala Schill. Bratislava 2014.

Mičianik 2019 - P. Mičianik: Malá vojna Mad'arska proti Slovensku 1938-1939. Banská Bystrica 2019.

Šteiner 2013 - P. Šteiner: Devät zlatých hviezd: hrdinovia alebo náhodný výber propagandy? Čata podporučíka Deputatova v obrane hronského predmostia. Studia Historica Nitriensia 17, 2013, 54-68.

Šteiner 2018 - P. Šteiner: Babylon armád 1. Boje medzi Iplom a Hronom, zima 1944-1945. Bratislava 2018.

Rukopis prijatý 10. 5. 2020

Translated by Pavol Šteiner
Šteiner 2019a-P. Šteiner: Babylon armád 2. Boje medzi Hronom a Váhom, február - apríl 1945. Bratislava 2019.

Šteiner $2019 b$ - P. Šteiner: Boje druhej svetovej vojny na juhozápadnom Slovensku v spomienkach priamych účastníkov, príslušníkov nemeckého Wehrmachtu. Memoárová literatúra ako vojenskohistorický prameň. Studia Historica Nitriensia 23, 2019, 171-192.

Vařeka 2013 - P. Vařeka: Úvod. In: P. Vařeka (ed.): Archeologie 19. a 20. století. Př́istupy - metody - témata. Plzeň 2013, 7-11.

doc. PhDr. Pavol Šteiner, PhD.

Katedra muzeológie FF UKF v Nitre

Hodžova 1

SK - 94901 Nitra

psteiner@ukf.sk 


\title{
Research of the Second World War Battlefields in Southwestern Slovakia Resources and Perspectives
}

\author{
Pavol Šteiner
}

\begin{abstract}
SUMMARY
One of the reasons, why archeology of modern conflicts in Slovakia has not yet been given a sufficient attention, is the fact, that even historical research of this era is not developed enough. However, the current legislation defines the militaria produced until 1946 as archaeological finds in case of finding them under the surface or under water. Thus they are on the same level as any artifacts, that archaeology accepts.

The most important area of the second world war combats covers the surface of districts Levice, Nové Zámky and Komárno, eventually neighbouring districts (Šal'a, Krupina, Nitra, Zlaté Moravce). They were the stage of heavy fighting between December 1944 and April 1945, since this had been a part of the strategical Budapest - Vienna strategical direction of the Red army.

According to written records, the best resources are provided mostly by Russian archives, publishing huge amounts of digitalized documents. Especially to be named server pamyat-naroda.ru publishing documents of the Red army units. Equally useful are Soviet-captured German

documents published by server wwii.germandocsinrussia.org.

Identifying certain battlefields and military postions requires also comparing the written records with map sources. These are mostly contemporary maps showing the terrain in shape it had been in 1940s. Up to these times we have the best experiences with 1938 special Czechoslovak military maps 1:75 000, Czechoslovak railway map 1:75 000 and Hungarian military maps of 1941.

Ploughing and other methods of soil-cultivating caused that field military objects from the second world war can be difficult to recognize on standard aerial or space photographs. That is why the great help is provided by LIDAR scanning, providing pictures free from plant-cover and is able to show irregularities not seen by other methods of observation.

The importance of archaeological research of second world war battlefields is rising because of presence of illegal archeological activities on these sites. Damages are done by inexpert recovering of artifacts without an appropriate documentation and by trading them, often abroad.
\end{abstract}

Fig. 1. An example of detailed situation map (source: https:// pamyat-naroda.ru).

Fig. 2. Professor J. Bátora is hodling a case of Soviet armourpiercing 7,62 $\mathrm{mm}$ shell found at the survey of perished farm Bibit puszta (author's archive).

Fig. 3. Comparation of space-photos on perished farm Bibit puszta taken at different cirsumstances (source: https:// zbgis.skgeodesy.sk).
Fig. 4. Continuous strip of the Wehrmacht field fortifications seen on LIDAR scans (source: https://zbgis. skgeodesy.sk).

Fig. 5. Dugouts for accomodation of soldiers, presumably of the Red army seen on LIDAR scans (source: https:// zbgis.skgeodesy.sk). 
